\title{
Public Security as a Cooperative Activity a Few Thoughts on the Social and Public Image of Law Enforcement Work
}

\author{
Mátyás Szabolcs \\ ORCID: 0000-0001-9529-7596 \\ János Sallai \\ ORCID: 0000-0001-6674-1942 \\ Tibor Szarvák \\ ORCID: $n / a$ \\ Miklós Tihanyi \\ ORCID: 0000-0003-2692-5389 \\ Vári Vince \\ ORCID:0000-0001-6416-1645 \\ National University of Public Service, Hungary
}

\begin{abstract}
Law enforcement is a unique, clearly delineated area of state involvement. Enhancing security is an important aim of state involvement, which affects diverse areas. Research thereon relate the interdisciplinary concept of security to conflicts and socio-economic crises. As a consequence, setting up a framework of policies for the topic demands a plurality of methods. The Good State and Governance report, published in 2015, names security and trust as defining spheres of influence. More specifically, the following 5 indicators presented as dimensions of public security and catastrophe management (citizens'sense of security in public places of their residential area; citizens' trust in the police; the number of registered wilful murders, intentional bodily injuries, and robberies; government expenditure on public order, civil protection, fire and catastrophe management per 1000 citizens; and the human resources of law enforcement) show well the importance of the common mindset associated with the Good State and Government special report. It is acknowledged that public security is a measurable social phenomenon; the objective state of private security is shown by criminal statistics; and public opinion concerning public security informs us about subjective security.
\end{abstract}

DOI: $10.5604 / 01.3001 .0014 .3185$

http://dx.doi.org/10.5604/01.3001.0014.3185

Keywords: law enforcement, public security, police, indicator

This paper is a compilation of analyses by the 'Good State - Good Police/Law Enforcement' task force. It was created by the task force of the Faculty of Law Enforcement of the National University of Public Service. Prof. Dr. Sallai János, Dr. Tihanyi Miklós, Dr. Vári Vince, Dr. Mátyás Szabolcs, consultant: Dr. Szarvák Tibor.

\section{Introduction}

Public security is a product of cooperation, which is a sum of the official services provided by the state, and the individual and collective accomplishments of selfdefence.' On the other hand, it is undeniable that the main element determining the level of public security is the police. This statement is especially true in light

1 Finszter G, Közbiztonság és jogállam, 2009. Electronic source: online.sze.hu/images/ J\%C3\%81P/2009/3/Finszter.pdf. accessed: 4.09.2019, p. 8. 
of the fact that Hungarian society expects the police to ensure public security, and holds them accountable for it. $^{2}$

In the earlier sections of our study, we have pointed out that security is a complex concept with several components. According to a study by Mátyás Szabolcs és Sallai János published in 2015, complex security has 6 components, with the economy, environment, defence, and pubic security as their main factors.

'In order to enforce the abstract standards of public welfare, the state has to take uptherole of creating and protecting valuesinthefield of politics, economyand society's.

The author sums up the processes relating to this statement under the headings of financial and economic crisis, effects of climate change, terrorism, and illegal immigration. We can describe the aspect of public policy in the same way as we handle the effects of personal and social (public) risks (their prevention and consequences). However, in today's complex world, it is difficult to treat the decrease of emergencies individually.

Accordingly, we can define the requirements of the content of 'good law enforcement', and specify the indicators that are capable - through the relevant measures - of enhancing the citizens' sense of security, along the principles of the concept of a good state ${ }^{4}$.

According to our hypothesis, this quality can be in essence identified with the change that law enforcement work achieves in the level of public security characterising society. At the forefront of our research is the social quality of law enforcement work, which has a complex definition with respect to public policy too.

This complex task is also important because in the past 25 years, the socioeconomic background that characterises the natural environment of complex law enforcement work has changed significantly.

It should definitely be mentioned that there are several offences, where the effects of changing the statistical method and raising the misdemeanour threshold to 50,000 forints did not and could not be felt.

\section{The results of the recent period - a few characteristic trends in criminal statistics}

In criminal statistics, which is held to be a manifestation of the state of public security, there have been significant changes recently.

In the case of certain offences (such as the fraudulent use of documents and non-cash paying instruments), the significant rise has not affected the subjective sense of security of the majority of citizens. No trends of constant increase or decrease could be determined concerning the individual crime types, and the operational criminal situation has not deteriorated.

${ }^{2}$ Barabás T, Irk F, Kovács R, Félelem, bünözés és bűnmegelőzés Európa öt nagyvárosában. Budapest, 2008.

3 Kaiser T (Ed.), Jó Állam Jelentés 2015. Budapest, 2015, p. 2.

${ }^{4}$ lbid. 
We can state that since 2012, the decrease in the numbers of crimes has been practically constant. Considering the figures of the past 4 years, the number of registered crimes has decreased by nearly 200,000 . What can be behind this constant decrease, which can now be considered statistically relevant?

It is often brought up as the reason for the decrease that the misdemeanour threshold has been raised, which has naturally reduced the number of known offences significantly. This was obviously a significant item in the single year when this act of decriminalisation was performed. However, it cannot account for the further significant decreases of the following years ${ }^{5}$.

From 2013, there has been a major decrease in the number of known offences (2013: 358,806, 2014: 309,394), which can be partly attributed to the modification of the statistical method mentioned above, and, according to several experts, the results of a stricter criminal policy, and further, a new interpretation of presence in public areas can also be felt behind the decrease.

Besides the quantitative change, we should also raise the topic of the qualitative change. Besides the decrease in the number of known crimes, several offences that greatly affect the subjective sense of security have also dropped in number. As regards the years between 2011 and 2015, it should definitely be highlighted that the number of robberies $(3202 \rightarrow 1442)$ and homicides $(327 \rightarrow 205)$ has constantly decreased. These two types of crimes have an especially great influence on the citizens' subjective sense of security. The number of larceny crimes has also decreased significantly, which - because of the great number of incidents - is one of the offences that have the greatest influence on national crime figures $(181,982 \rightarrow 111,324)$. It is evident that raising the misdemeanour threshold has also contributed to the significant drop in the number of incidents; however, even if we do not consider this, the number of known thefts has decreased.

Based on the above, we can state that considering the crime statistics data of the past six years, the number of known crimes has indeed decreased. Practically speaking, the last time that saw such low crime figures was the period around the change of regime.

Besides traditional statistical tendencies, we should also mention that along with a general improvement, a mosaic interpretation of the data is also available.

In an international collection of studies on police forces, published in 2013, the author of the chapter on Hungary points out that while the risk of becoming a victim is relatively low, the sense of security is not higher than the EU average ${ }^{6}$.

All in all, the decrease in the number of registered violent crimes in the representative group indicates a measurable improvement of the government's power to prevent and fight crimes. Law enforcement capacities have increased, state

${ }^{5}$ If we include both misdemeanours and crimes, we still see a decrease.

${ }^{6}$ Leyrer R, Finding the Right Path of Policing in Hungary, [in:] Gorazd Mesko (Ed.), Handbook on Policing in Central and Eastern Europe. New York, Springer science, Business Media, 2013, p. 126; Christián L, A rendőrségre és a titkosszolgálatokra vonatkozó szabályozás változásai. MTA Law Working Papers, 2014. Electronic source: http://jog.tk.mta.hu/uploads/ files/mtalwp/2014_43_Christian.pdf, accessed:06.04.2019. 
expenditures on public order have grown, and the human resources of law enforcement have increased. Trust in the legal system has strengthened ${ }^{7}$.

\section{Possibilities of measurement and assessment in light of territorial influences}

Due to its cooperative nature, the state of public security is influenced by several factors besides the activities of the police. Thus, it is hard to form a clear picture of the quality of the work of the police merely based on public security data.

As Sallai János put it in Belügyi Szemle (Internal Review) in 2014, police (and law enforcement science) also draw upon the findings of criminal geography. This appears in the aspects of the Good State and Governance Report, which states that the data of macro statistics and organisational performance reviews should be analysed in light of the characteristics of locality.

In his already-quoted study, Bíró Gyula highlights the following local aspects out of the defining components of public security:

Criminal/traffic factors: tendencies in the number of crimes occurring in the narrow or broader living environment - in the citizens' proximity — and the 'quality' of the crimes in the direct living environment, and furthermore, the traffic conditions of the routes most frequently used by the individual.

Factors related to the order of public areas: the condition of public lighting in the immediate living environment of the individual and around their place of work, and sanitation conditions in their immediate surroundings.

Factors related to human relationships and human communication:

- the relationship between the individual and police officers;

- the police presence in public areas;

- the quality of the police's response ability;

- the quality of police and press communication concerning the various crimes;

- the presence of the police community support officers in public areas.

When examining social influences, an analysis of integrated urban development strategies can become important background material too. Based on the

7 According to a survey by TÁRKI, trust in the Hungarian legal system has increased between 2009 and 2013 (from 4.0 to 4.78). The 2014 survey by KSH (Hungarian Central Statistical Office) used a different methodology, and produced a score of 5.1 on a scale ranging to 10 , which could become the baseline data for measuring trust in the future (Good State and Governance Report, 2015, p. 6). TÁRKI's survey on trust in institutions has shown a significant increase of trust in the police between 2009 and 2013. Out of the public institutions examined by TÁRKI, the police achieved the second highest trust index after MTA (and received a higher score than the Parliament, the Central Bank of Hungary and the State Accounting Office). (Good State and Governance Report, 2015, p. 14).

${ }^{8}$ Bíró G, A közbiztonság és a közlekedésbiztonság egyes kérdései, különös tekintettel a balesetmegelőzésre, [in:] Rendészeti kutatások - a rendvédelem fejlesztése című tudományos konferenciáról szóló tanulmányok, 2011. Electronic source: http://pecshor.hu/ periodika/XII/birogy.pdf, accessed: 12.09.2019. 
background material needed for its preparation (Dietz, 2011), we can see that the question of public order is an important methodological and (regional) conceptional component.

In task forces, the question of public order is treated together with economic activity and employment, the situation of young people, the question of immigrants, the delineation of the targets of urban rehabilitation, and citizens' involvement.

\section{Summary - Forming indicator groups for the social - public image of law enforcement work}

From a profession history/science history point of view, the scholars of law enforcement science saw cooperation between professions and sciences as components of successful law enforcement work.

The first person to define the concept of Hungarian law enforcement in Hungarian, Karvasy Ágoston, thought 'law enforcement science is a science that presents the principles according to which the inner sense of security and public order in the state shall be protected against all possible violations and accidents, and if this cannot be achieved by the institutions of law enforcement, all of the knowledge of the citizens shall promote it; and according to which, the personnel assigned to the objectives of this science are called police ${ }^{\prime 9}$.

We can also use Karvasy Ágost's thoughts to delineate the character of 19th century 'good state - good law enforcement'. The author is right in seeing that the knowledge of the citizens is also an important factor of good law enforcement.

According to Karvasy's work ${ }^{10}$, the below requirements are important for good policing:

- They should be familiar with the general principles of public policing science, and the specific rules of the police of their country.

- They should have sound judgement, presence of mind, and quick resourcefulness.

- In their jobs, they should be hardworking and incorruptible, and should be enthusiastic about public welfare.

- In their actions, they should show earnestness, vigour, and firmness, moderated by mildness and humanity."11

In our study supporting the development of good law enforcement, we have aimed at examining the factors that can have an impact on the citizens'/communities' subjective sense of security, and the objective state of public security, which can be expressed by figures.

Based on the complexity of policing, and the manifold relationship between this field and other subsystems, we can say that the social dimension accounts

${ }^{9}$ Karvasy Á, A politicai tudományok rendszeresen előadva. I-III. Győr, Streibig, 1843-1844, p. 91.

10 Karvasy Á, A közrendészeti tudomány és culturpolitika. Pest, 1870.

11 lbid. 
for a (in our opinion, great) segment of the performance evaluation of the police organisation. Theoretically speaking, all of this sometimes weakens and at other times strengthens the organisation's operation.

Thus, in the first stage of the 'Good Law Enforcement' research programme, it is important to make recommendations concerning the dimensions and factors related to the enhancement of security.

In the second stage, we include community planning, in the course of which we consult experts on how they see the public policy elements of good law enforcement and the questions treated by the study, the special local/community agents of security, the quality of partnership concerning law enforcement work, and the process by which we measure the social aspect of the impacts of police activities.

It is an important statement of our paper that different local characteristics require a different system of organisational, personnel, and technical conditions to ensure that police bodies working in different geographical areas can provide at least roughly the same quality of services. Thus we give priority to formulating quality indicators instead of the indicators of organisational performance reviews. These can be capable of showing what added value the work of law enforcement bodies has with respect to improving the subjective-objective sense of security in a given region, and more specifically, what input values need to be changed in order for output values to change in a positive way.

The formulation of integrated social impact indicators is a very important step towards that goal, which provides help in the design and implementation of complex sectoral and territorial public policy programmes.

Based on the definition of the 6 areas of influence, we can state that the area of influence of community/partnership is the one that is socially and territorially embedded in the most complex way. All of this can be seen as a basic and applied research task, the result of which also controls the sense of security.

Channelling citizens' opinions is an area of applied research, and considering their impact, is also complex: it affects the user and the employer/maintainer at the same time. Thus it can be seen as having an aspect of organisational sociology, since the achievements of the sphere of influence reflect the efficiency of the organisation's human resource and budget management too.

The sphere of influence of victim protection is also defined by law enforcement science and social politics. This section also discusses the probability and regional characteristics. The region has an important influence on the sense of objective/ subjective security.

Three of the spheres of influence that we have listed (intervention, efficient investigation, and the maintenance of public order) are rather law enforcement tasks in the narrow sense.

\section{References}

1. Barabás T, Irk F, Kovács R, Félelem, bűnözés és bűnmegelőzés Európa öt nagyvárosában. Budapest, 2008.

2. Bíró Gy, A közbiztonság és a közlekedésbiztonság egyes kérdései, különös tekintettel a balesetmegelőzésre, [in:] Rendészeti kutatások - a rendvédelem fe- 
jlesztése című tudományos konferenciáról szóló tanulmányok, 2011. Electronic source: http://pecshor.hu/periodika/XII/birogy.pdf

3. Brunet J.R, Measuring social equity performance in the criminal justice system. Paper presented at the Fifth Social Equity Leadership Conference, Omaha, NE, 2006.

4. Charbonneau E, Riccucci N. M, Beyond the usual suspects: An analysis of the performance measurement literature on social equity indicators in policing. Public Performance and Management Review, 2008, 31(4), pp 604-620.

5. Christián $L, A$ rendőrségre és a titkosszolgálatokra vonatkozó szabályozás változásai. MTA Law Working Papers, 2014. Electronic source: http://jog.tk.mta.hu/ uploads/files/mtalwp/2014_43_Christian.pdf

6. Christián L, Rendészeti politika. MTA, Law Working Papers, 2015. Electronic source: http://jog.tk.mta.hu/uploads/files/mtalwp/2015_14_Christian.pdf

7. Collier P.M, Police performance measurement and human rights. Public Money \& Management, 2001, Vol. 21, Issue 3, pp 35-40.

8. Concha Gy, Politika II. Budapest, 1905.

9. Dietz F, Az integrált városfejlesztési stratégia, 2011. Electronic source: www.tankonyvtar.hu/hu/tartalom/tamop412A/.../05_Integralt_varosfejlesztes.pdf

10. Electronic source: http://www.justiceinspectorates.gov.uk/hmic/

11. Electronic source: http://www.parlament.hu/irom39/00047/00047.pdf, A Nemzeti Együttmüködés Programja.

12. Feilzer, Not fit for purpose! The (ab-)use of the British Crime survey as a performance measure for individual police forces. Policing: A Journal of Policy and Practice, 2009, Vol. 3, Issue 2, pp 200-211.

13. Finszter G, A rendőrség joga. Budapest, 2014.

14. Finszter G, Egy kutatás tervezése. Magyar Rendészet, 2015, Vol. 3.

15. Finszter G, Közbiztonság és jogállam, 2009. Electronic source: online.sze.hu/ images/J\%C3\%81P/2009/3/Finszter.pdf

16. Finszter $G$, Rendészetelmélet. Budapest, 2014.

17. Grizzle G.A, Performance measurement and dysfunction: The dark side of quantifying work. Public Performance \& Management Review, 2002, Vol. 25, Issue 4.

18. Hatry H.P, Performance measurement principle and techniques: An overview for local government. Public Productivity Review, 1980, Vol. 4, Issue 4.

19. Hough M, Policing London, 20 Years on, [in:] Henry A, Smith D. J (Ed.), Transformations of Policing. Aldershot, Ashgate, 2007.

20. Hough M, Policing, New Public Management, and Legitimacy in Britain, [in:] Tyler T. R (Ed.), Legitimacy and Criminal Justice: International Perspectives. New York, Sage, 2007.

21. Irk F, Közbiztonságtan. Budapest, 70, 2007.

22. Irk F, Közlekedésbiztonság és bűnözéskontroll. Budapest, 2003.

23. Jennings E.T. Jr., Haist M.: Performance measurement - Symbol of substance?, 2003.

24. Kaiser T (Ed.), Jó Állam Jelentés 2015. Budapest, 2015.

25. Kaiser T, Az államkutatások helye a társadalomtudományok rendszerében. Államtudományi Mühelytanulmányok, 2016/1. Electronic source: http://uni-nke.hu/ uploads/media_items/2016-1-az-allamkutatasok-helye-a-tarsadalomtudomanyok-rendszereben.original.pdf 
26. Kardos $P, A$ polgárőrség", [in:] Miklós T (Ed.), A rendészeti feladatot ellátó szervek és a polgárőrség. Budapest, 2015.

27. Kovács $S$, Rendészeti szabályozás, [in:] Miklós T (Ed.), A rendészeti feladatot ellátó szervek és a polgárőrség. Budapest, 2015.

28. Leyrer R, Finding the Right Path of Policing in Hungary, [in:] Mesko G (Ed.), Handbook on Policing in Central and Eastern Europe. New York, Springer science, Business Media, 2013.

29. Major R, Tihanyi M, Kovács S, Vajda A, A nagyvárosi lakosság szubjektív biztonságérzetének javíthatósága. Belügyi Szemle, 2014, Vol. 5.

30. Mátyás Sz, A Debreceni Rendőrkapitányság elkövetői és bűnelkövetői vonzáskörzete. Magyar Rendészet, 2012, Vol. 2.

31. Myhill A, Quinton, P Confidence, Neighbourhood Policing, and Contact: Drawing Together the Evidence. Policing: A Journal of Policy and Practice, 2010, Vol. 4, Issue 3.

32. Patyi A, Szalay P, Varga Zs. A: Magyarország alkotmányának szabályozási elvei. Szakértői változat, 2012 (http://d18wh0wf8v71m4.cloudfront.net/docs/ wp/2012/2011-31.pdf).

33. Remek É, A nagyvárosok közbiztonsági és szubjektív biztonsági helyzete Különös tekintettel a válság és a jól-lét fogalmára, [in:] Hervainé dr. Szabó Gyöngyvér, Folmeg Márta (Ed.), Társadalmi válságok, konfliktusok a jól-lét kontextusában. Székesfehérvár, Kodolányi János Főiskola, pp 59-79, 2015.

34. Rogge, Nicky Verschelde, Marijn: A composite index of citizen satisfaction with local police services. Hub Research Papers, Economics \& Managment, 2012/13.

35. Sallai J, Bünözésföldrajz: a rendőrség szolgálatába állított tudomány. Belügyi szemle, 2010, Vol. 62, Issue 9, pp 95-107.

36. Sallai J, Mátyás Sz, Objektív és szubjektív biztonság néhány magyar nagyvárosban, [in:] Hervainé Szabó Gyöngyvér (Ed.), A 21. Század eleji államiság kérdőjelei. Székesfehérvár, Kodolányi János Főiskola, 2015.

37. Shilston T.G, Black box: A qualitative method for improving public confidence in policing through micro-analysing service delivery. Policing: A Journal of Policy and Practice, 2011, Vol. 5, Issue 2, pp 125-131.

38. Smuk $P$, Kocsis $M, A$ jogállamiság 20 éve - tudományos konferencia Győrött. Közjogi Szemle, 2009, Vol. 3. pp 70-71.

39. Szarvák T, Jász K, Bozorádi J, A családon belüli erőszakról egy kutatás tükrében. Szolnok, Országos Bűnmegelőzési Központ, Szolnok Önkormányzat, Szolnok Rendőrkapitányság, 2006.

40. Szirtes K, Pillanatkép a megélhetési bűnözésről. 2010. Electronic source: http:// www.kimisz.gov.hu/data/cms26135/Szirtes_Klara_Pillanatkep_a_megelhetesi_bunozesrol.pdf

41. Team Consult jelentés. Budapest, 1990.

42. Tihanyi M, A városok problémái, [in:] Korinek László, Értekezések a rendészetről. Budapest, 2015.

43. Vári Vince, $A$ bünüldözés relatív hatékonysága és a rendőrség. PhD dissertation Miskolc, Miskolci Tudományegyetem Állam-és Jogtudományi Kar, Deák Ferenc Doktori Iskola, 2015.

44. Young M, An inside job: Policing and police culture. Oxford, Clarendon Press. Working paper. University of Kentucky, 1991. 


\title{
About the Authors
}

Szabolcs Mátyás, PhD police major, assistant professor National University of Public Service, Faculty of Law Enforcement, Hungary. Academic/research interests: criminal geography, criminalistics, predictive policing, tourism.E-mail: matyas.szabolcs@uni-nke.hu

János Sallai, PhD police colonel, professor National University of Public Service, Faculty of Law Enforcement, Hungary. Academic/research interests: security, law enforcement, history. E-mail: sallai.janos@uni-nke.hu

Vince Vári, PhD police lieutenant-colonel, assistant lecturer National University of Public Service, Faculty of Law Enforcement, Hungary. Academic/research interests: diversion in crime investigation, police performance measurement, police efficiency, criminal investigation. E-mail: vari.vince@uni-nke.hu

Miklós Tihanyi, PhD police major, assistant lecturer National University of Public Service, Faculty of Law, Hungary. Enforcement Academic/research interests: law enforcement, criminology, canon law.E-mail:miklos.tihanyi@uni-nke.hu

Tibor Szarvák, PhD. assistant professor National University of Public Service, Hungary. Academic/research interests: sociology, social geography, social policy. e-mail: drszarvaktibor@ gmail.com

\begin{abstract}
Streszczenie. Egzekwowanie prawa to wyjatkowy, jasno określony obszar zaangażowania państwa. Poprawa bezpieczeństwa jest ważnym celem zaangażowania państwa, który obejmuje różnorodne obszary. Badania w tym zakresie wiq̨ż interdyscyplinarnq koncepcję bezpieczeństwa z konfliktami i kryzysami społeczno-gospodarczymi. W zwiqzku z tym, stworzenie ram polityki w tym zakresie wymaga zastosowania licznych metod. Raport o dobrym stanie i zarządzaniu, opublikowany w $2015 \mathrm{r}$., określa bezpieczeństwo i zaufanie jako definiujące strefy wpływów. Ściślej rzecz biorq̨, pięć wskaźników przedstawionych jako wymiary bezpieczeństwa publicznego i zarzqdzania katastrofami, tj:: poczucie bezpieczeństwa obywateli w miejscach publicznych na obszarze ich zamieszkania; zaufanie obywateli do policji; liczba zarejestrowanych umyślnych zabójstw, umyślnych uszkodzeń ciała i rozbojów; wydatki rzq̨dowe na porządek publiczny, ochronę ludności, zarzq̨dzanie pożarami i katastrofami na 1000 obywateli; oraz zasoby ludzkie organów ścigania dobrze ukazuja znaczenie wspólnego sposobu myślenia zwiqzanego ze specjalnym sprawozdaniem pt. Dobre Państwo i Rząd. Uznaje się, że bezpieczeństwo publiczne jest wymiernym zjawiskiem społecznym, obiektywny zaśstan bezpieczeństwa prywatnego odzwierciedlają statystyki kryminalne, a opinia publiczna dotyczqca bezpieczeństwa publicznego informuje o bezpieczeństwie subiektywnym.
\end{abstract}

Zusammenfassung. Die Strafverfolgung ist ein einzigartiger, klar definierter Bereich staatlicher Beteiligung. Die Verbesserung der Sicherheit ist ein wichtiges Ziel der staatlichen Beteiligung, das eine Vielzahl von Bereichen abdeckt. Die Forschung in diesem Bereich verbindet das interdisziplinäre Sicherheitskonzept mit Konflikten und sozioökonomischen Krisen. Daher erfordert die Schaffung eines politischen Rahmens in diesem Bereich den Einsatz zahlreicher Methoden. In einem 2015 veröffentlichten Bericht über guten Zustand und Management werden Sicherheit und Vertrauen als definierende Einflussbereiche identifiziert. Genauer gesagt, fünf Indikatoren, die als Dimensionen der öffentlichen Sicherheit und des Katastrophenmanagements dargestellt werden, d. h. Ein Gefühl der Sicherheit der Bürger an öffentlichen Orten in ihrem Wohngebiet, dann das Vertrauen der Bürger in die Polizei, weiter die Anzahl der registrierten vorsä̈zlichen Tötungen sowie vorsätzlichen Körperverletzungen und Raubüberfälle, demnächst Staatsausgaben für öffentliche Ordnung, und anschließend Katastrophenschutz, Feuer- und Katastrophenmanagement pro 1.000 Bürger. Die Personalabteilung der Strafverfolgungsbehörden zeigt deutlich, wie wichtig gemeinsames Denken im Zusammenhang mit dem Sonderbericht 'Guter Staat und Regierung' ist. Es wird anerkannt, dass die öffentliche Sicherheit ein messbares, soziales Phänomen ist, der objektive Zustand der privaten Sicherheit sich in der Kriminalstatistik widerspiegelt während die öffentliche Meinung zur öffentlichen Sicherheit uns über die subjektive Sicherheit informiert. 
Резюме. Эффективное правоприменение - это уникальная, четко определенная сфера государственного участия. Повышение уровня безопасности является важной задачей государства, охватывающей целый ряд вопросов. Исследования в этой сфере связывают междисциплинарную концепцию безопасности с конфликтами и социально-экономическими кризисами. Следовательно, разработка основ политики в этой области требует применения ряда методов. В Докладе о стабильности положения и эффективности управления, опубликованном в 2015 году, безопасность и доверие определяются как факторы, характеризующие зоны влияния. Если говорить более точно, то пять показателей, представленных в качестве параметров общественной безопасности и управления деятельностью в случае стихийных бедствий, т.е.: чувство безопасности граждан в общественных местах, в районе их места проживания; довереие граждан к полиции; число зарегистрированных умышленных убийств, умышленых телесных повреждений и разбойных нападений; правительственные издержки на обеспечение общественной безопасности, управление пожарами и стихийными бедствиями на 1000 жителей, а также человеческие ресурсы органов преследования хорошо определяют значение общего способа пониманя, заключенного в специальном докладе «Хорошее государство и Правительство». (читается, что общественная безопасность является измеримым социальным явлением, а объективное состояние личной безопасности отражается в статистике преступности. Кроме того, общественное мнение на тему общественной безопасности предоставляет информацию о субъективной безопасности. 